\title{
COMPOSITION OF THE ESSENTIAL OIL FROM MIMOSA PUDICA LINN.
}

\author{
VISMAYAVISWAN TK, DHARANI J, SRIPATHI R, RAVI S*
}

Department of Chemistry, Karpagam Academy of Higher Education, Karpagam University, Coimbatore, Tamil Nadu, India. Email: ravisubban@rediffmail.com

Received: 01 September 2018, Revised and Accepted: 28 December 2018

ABSTRACT

Objectives: The objectives of this study were to determine the composition of the essential oil obtained from Mimosa pudica L. (Mimosaceae).

Methods: The essential oil of M. pudica was obtained by hydrodistillation using a Clevenger apparatus, and the chemical composition was determined by gas chromatography-mass spectrometry analysis.

Results: About 23 compounds were identified from the essential oil which constitutes about 98.92\% of the oil. Among the compounds identified, phthalic acid dioctyl ester (27.76\%), $\alpha$-linolenic acid (20.34\%), and cinnamaldehyde (16.24\%) are the major compounds. $\alpha$-linolenic acid is an n-3 fatty acid.

Conclusion: $\alpha$-linolenic acid is one of the essential fatty acids, which is necessary for health and cannot be produced within the human body. M. pudica L. (Mimosaceae) appears to be a promising herb to undergo a wide exploration.

Keywords: Essential oil, Mimosa pudica Linn., Mimosaceae, Gas chromatography-mass spectrometry analysis, Fatty acids.

(C) 2019 The Authors. Published by Innovare Academic Sciences Pvt Ltd. This is an open access article under the CC BY license (http://creativecommons. org/licenses/by/4. 0/) DOI: http://dx.doi.org/10.22159/ajpcr.2019.v12i3.29444

\section{INTRODUCTION}

Mimosa pudica Linn. belongs to the family Fabaceae is a small-sized tree and is used in Ayurvedic medicine. The leaves are very sensitive, both pinnae and leaflets folding when touched [1,2]. It is commonly distributed in roadside, walkway, marsh and hillside areas, so this plant is neglected weed growing in dumps [3]. M. pudica relives "Odu vaatham" a kind of vaatha disease [4]. Recently, extracts of $M$. pudica Linn. were found a multitude of therapeutic properties. Diuretic [4], psoriasis cure [5], swelling, wounds healing [6], antioxidant, antimicrobial, antiinflammatory [7], antidiabetic, anticancer, cardiovascular disease [8], hypolipidemic, antimicrobial activity [9], anticonvulsant [10], antimalarial, antifertility, fistula [11], cough, influenza [12], systemic infections, snakebite areas [13], hepatoprotective activity [14], antidepressant [15], leprosy, hypoglycemic, pulmonary tuberculosis, neurasthenia [16], atherosclerosis, hyperglycemic [17], and various urogenital infections [18] have been attributed in different parts of M. pudica. Regarding the secondary metabolite potential of $M$. pudica, it has been reported that it contains nitrogen-containing compounds, phenolic compounds, sitosterols, fatty compounds, and rich source of flavonoids [19]. M. pudica Linn. is famous for its anticancer alkaloid mimosine [20] and includes a kind of 5-deoxyflavonols, particularly. Many phytoconstituents were reported from the plant leaves, seed, stem, root, and the whole aerial parts of M. pudica [21-24]. Even though a good number of phytoconstituents were isolated and characterized, the chemical composition of the essential oil was not yet carried out. Knowledge of the chemical constituents of plants is desirable to discover new therapeutic agents and to find the actual significance of folkloric remedies [25]. In the present work, the essential oil has been obtained from M. pudica Linn., and its chemical composition was determined.

\section{METHODS}

Plant material and essential oil extraction

The fresh leaves of $M$. pudica Linn. were collected from Coimbatore, South India, during the winter season in the month of January 2018. The authentication of the plant was done by the Botany Department,
Karpagam Academy of Higher Education, Coimbatore, and a voucher specimen was preserved.

The fresh aerial part $(1 \mathrm{~kg}$ ) leaves of $M$. pudica were subjected to hydrodistillation using Clevenger type apparatus $(4 \times 3 \mathrm{~h}=12 \mathrm{~h})$. The resulted aqueous layer from the Clevenger apparatus was collected and extracted with petroleum ether $(4 \times 25 \mathrm{ml})$ and dried over anhydrous sodium sulfate and then concentrated in a water bath to yield a slight yellowish oil $(0.26 \%(\mathrm{v} / \mathrm{w})$.

\section{Gas chromatography-mass spectrometry (GC-MS) analysis}

GC-MS along with an ESI system with the ionization energy of $70 \mathrm{eV}$ was utilized for analysis. Helium (99.99\%) was used as carrier gas, with the flow rate of $1 \mathrm{ml} / \mathrm{min}$. The injection port temperature was set at $250^{\circ} \mathrm{C}$, and initial column temperature was kept at $40^{\circ} \mathrm{C}$ for $1 \mathrm{~min}$ and then gradually increased to $230^{\circ} \mathrm{C}$ at the flow rate of $3^{\circ} \mathrm{C} / \mathrm{min}$. The components were identified by comparing their mass spectra with those in the GC-MS library and literature and by comparing their relative retention times by those of authentic samples on the HP-5 MS capillary column.

\section{RESULTS AND DISCUSSION}

Biological activities of aromatic plants are in part attributed to essential oils which are used as flavoring additives to cosmetics, disinfection agents, and medicinal means for a long time. The essential oil was obtained from $M$. pudica Linn. by hydrodistillation using a Clevenger type apparatus, and the composition is determined by GC-MS analysis for the $1^{\text {st }}$ time. The result is exhibited in the Table 1 . Twenty-three compounds were identified from the essential oil which constitutes about $98.92 \%$ of the oil. Among the compounds identified, phthalic acid dioctyl ester (27.76\%), $\alpha$-linolenic acid (20.34\%), and cinnamaldehyde $(16.24 \%)$ are the major compounds. $\alpha$-linolenic acid is an $n-3$ fatty acid. It is one of two essential fatty acids because they are necessary for health and cannot be produced within the human body.

Earlier GC-MS analysis was carried out on the methanol extract of M. pudica Linn., and 19 compounds were identified and reported. 
Table 1: Composition of the essential oil obtained from M. pudica Linn.

\begin{tabular}{llll}
\hline Compound name & Molecular formula & Molecular weight & Retention index (\%) \\
\hline Ethanol 2-methoxy acetate & $\mathrm{C}_{5} \mathrm{H}_{10} \mathrm{O}_{3}$ & 118 & $761(7.1)$ \\
Phthalic acid dioctyl ester & $\mathrm{C}_{24} \mathrm{H}_{38} \mathrm{O}_{4}$ & 390 & $2832(27.76)$ \\
Methyl octylester & $\mathrm{C}_{9} \mathrm{H}_{20} \mathrm{O}$ & 144 & $992(0.36)$ \\
3-Pinanone & $\mathrm{C}_{10} \mathrm{H}_{16} \mathrm{O}$ & 152 & $1109(1.9)$ \\
$\alpha$-Linolenic acid & $\mathrm{C}_{18} \mathrm{H}_{30} \mathrm{O}_{2}$ & $2191(20.34)$ \\
Phytol & $\mathrm{C}_{20} \mathrm{H}_{40} \mathrm{O}$ & $2045(4.08)$ \\
n-Hexadecanoic acid & $\mathrm{C}_{16} \mathrm{H}_{32} \mathrm{O}_{2}$ & $1968(2.74)$ \\
Dibutyl phthalate & $\mathrm{C}_{16} \mathrm{H}_{22} \mathrm{O}_{4}$ & 296 & $2037(0.7)$ \\
7,9-Di-tert-butyl-1-oxaspiro (4,5) deca-6,9-diene-2,8-dione & $\mathrm{C}_{17} \mathrm{H}_{24} \mathrm{O}_{3}$ & 256 \\
1,2-Benzenedicarboxylic acid, bis (2-methylpropyl) ester & $\mathrm{C}_{16} \mathrm{H}_{22} \mathrm{O}_{4}$ & 278 & $1908(1.68)$ \\
Tetradecanoic acid & $\mathrm{C}_{14} \mathrm{H}_{28} \mathrm{O}_{2}$ & 276 & $1769(0.5)$ \\
1-Pentadecene & $\mathrm{C}_{15} \mathrm{H}_{30}$ & $1502(0.38)$ \\
Dodecanoic acid & $\mathrm{C}_{12} \mathrm{H}_{24} \mathrm{O}_{2}$ & 278 & $1570(3.36)$ \\
1,6,10-Dodecatrien-3-ol, 3,7,11-trimethyl-, & $\mathrm{C}_{15} \mathrm{H}_{26} \mathrm{O}$ & $1564(0.62)$ \\
Phenol, 2,4-bis (1,1-dimethylethyl)- & $\mathrm{C}_{14} \mathrm{H}_{22} \mathrm{O}$ & 228 & $1555(0.86)$ \\
3-Buten-2-one, 4-(2,6,6-trimethyl-1-cyclohexen-1-yl) & $\mathrm{C}_{13} \mathrm{H}_{20} \mathrm{O}$ & $1457(0.8)$ \\
Phenol, 2-methoxy-3-(2-propenyl)- & $\mathrm{C}_{10} \mathrm{H}_{12} \mathrm{O}_{2}$ & 210 & $1392(0.86)$ \\
2-Methoxy-4-vinylphenol & $\mathrm{C}_{9} \mathrm{H}_{10}$ & 200 & $1293(5.1)$ \\
Indole & $\mathrm{C}_{8} \mathrm{H}_{7} \mathrm{~N}$ & 222 & $1174(0.56)$ \\
Cinnamaldehyde & $\mathrm{C}_{9} \mathrm{H}_{8} \mathrm{O}$ & 192 & $1189(16.24)$ \\
2,3-Dihydrobenzofuran & $\mathrm{C}_{8} \mathrm{H}_{8} \mathrm{O}$ & 164 & $1036(1.44)$ \\
Benzene methanol & $\mathrm{C}_{7} \mathrm{H}_{8} \mathrm{O}$ & 117 & $1036(0.43)$ \\
3-Hexen-1-ol & $\mathrm{C}_{6} \mathrm{H}_{12} \mathrm{O}$ & 132 & $868(2.08)$ \\
\hline
\end{tabular}

Myoinositol (46.61\%), squalene (18.21\%), and Vitamin E (12.76\%) were the major compounds [26]. In another study, the GC-MS of the oil extract of M. pudica Linn. showed that the presence of N-dlalanylglycine, dl-alanyl-dl-valine, d-alanin, dl-alanin ethyl ester, 1-alanine ethyl amide, 9, 12-octadecadienoic acid (Z, Z), methyl ester, 9, 12-octadecadienoic acid, methyl ester, 11, 13-eicosadienoic acid, methyl ester, and meglumine was reported [27]. In the present study, the major compounds identified from the essential oil were entirely different from the volatile constituents present in the methanol extract [26] or the oil extract of M. pudica Linn. [27]. Alpha-linolenic acid is popular for preventing and treating diseases of the heart and blood vessels. It is used to prevent heart attacks, lower high blood pressure, lower cholesterol, and reverse "hardening of the blood vessels" (atherosclerosis) [28]. Cinnamaldehyde possesses antibacterial and antifungal activities and restricts the harmful blood platelet clotting.

\section{CONCLUSION}

M. pudica is traditionally very important herb having many important pharmacological activities. Many important phytoconstituents responsible for the activity were identified in the essential oil by GC-MS. Among the compounds identified, phthalic acid dioctyl ester (27.76\%), $\alpha$-linolenic acid (20.34\%), and cinnamaldehyde (16.24\%) are the major compounds. This proves the therapeutic importance of the plant. Such type of systematic information about the plant is useful for the researchers.

\section{AUTHORS' CONTRIBUTIONS}

Vismayaviswan TK and Dharani J have carried out the work and prepared the manuscript. Sripathi R helped in the GC-MS analysis and S. Ravi has guided and has done modification and editing of the manuscript.

\section{CONFLICTS OF INTEREST}

The authors declared that they have no conflicts of interest.

\section{REFERENCES}

1. Lubna A, Manish KS, Ali KA. Pharmacological and biological overview of Mimosa pudica Linn. Int J Pharm Life Sci 2011;2:1226-34.

2. Rajeshwari S, Raghunath P. GC-MS Studies of Mimosa pudica. Int J Pharmtech Res 2012;4:93-8.
3. Tunna TS, Zaidul IS, Ahmed QU, Ghafoor K, Al-Juhaimi FY, Uddin MS, et al. Analyses and profiling of extract and fractions of neglected weed Mimosa pudica Linn, traditionally used in Southeast Asia to treat diabetes. South Afr J Botany 2015;99:144-52.

4. Mahadevan MV, Ramaswamy RS, Banumathi V. Mimosa pudica exerts neuroprotection against MPP+ induced neurotoxicity in SHSY5Y cell lines- an in vitro model of anti-parkinsonism. Int J Pharm Pharm Sci 2017;9:21-6.

5. Baghel A, Rathore DS, Gupta V. Evaluation of diuretic activity of different extracts of Mimosa pudica linn. Pak J Biol Sci 2013;16:1223-5.

6. Ignacimuthu S, Ayyanar M, Sankarasivaraman K. Ethnobotanical study of medicinal plants used by Paliyar Tribals in Theni district of Tamil Nadu, India. Fitoterapia 2008;79:562-8.

7. Paul J, Khan S, Mohammed S, Khan S, Asdaq SM. Wound healing evaluation of chloroform and methanolic extracts of Mimosa pudica roots in rats. Indian J Phys Anthropol Hum Genet 2010;1:223-7.

8. Chowdhury S, Saha D, Paul S. In vitro cytotoxic activities of methanolic extract of Mimosa pudica. Bull Pharm Res Inst 2012;2:42-5.

9. Balunas MJ, Kinghorn AD. Drug discovery from medicinal plants. Life Sci 2006;78:431-41.

10. Tamilarasi T, Ananthi T. Phytochemical analysis and anti-microbial activity of Mimosa pudica Linn. Res J Chem Sci 2012;2:72-4.

11. Ngo Bum E, Dawack DL, Schmutz M, Rakotonirina A, Rakotonirina SV, Portet C, et al. Anticonvulsant activity of Mimosa pudica decoction. Fitoterapia 2004;75:309-14.

12. Rahman AH, Debnath A. Ethno-botanical Study at the Village Pondit Para under Palash Upazila of Narsingdi District, Bangladesh. Int J Adv Res 2015;3:1037-52.

13. Pandey A, Singh S, Singh R, Rajashree G Mavinkurve. Use of indigenous plants in traditional health care systems and economic use by Mishing tribe of Jorhat, Assam, India. World J Pharm Sci 2015;4:1277-89.

14. Vijayakumar S, Morvin Yabesh JE, Prabhu S, Manikandan R, Muralidharan B. Quantitative ethnomedicinal study of plants used in the Nelliyampathy hills of Kerala, India. J Ethnopharmacol 2015;161:238-54.

15. Rekha R, Hemalatha S, Akasakalai K, Krishna CH, Sohil B, Sundaram RV. Hepatoprotective activity of Mimosa pudica Leaves against carbon tetrachloride induced toxicity. J Nat Prod 2009;2:116-22.

16. Zaware BB, Chaudhari SR, Shinde MT. An overview of Mimosa pudica Linn. Chemistry and pharmacological profile. Res J Pharm Biol Chem Sci 2014;5:754-61

17. Yuan J. Two new C-glycosyl flavones from Mimosa pudica. Chin Chem Lett 2007;18;1231-4.

18. Rajalakshmi K, Banu N. Antimicrobial activity of natural chlorophyllin from endangered medicinal plant Mimosa pudica L. Int J Pharm Pharm Sci 2016;8:387-9.

19. Kaur P, Kumar N, Shivananda TN, Kaur G. Phytochemical screening and antimicrobial activity of the plant extracts of Mimosa pudica L, 
against selected microbes. J Med Plants Res 2011;5:5356-9.

20. Renz J, Mimosine Z. Uber das mimosin. Zeitschrift fur . Physiol Chem 1936;244:153-8.

21. Jha NK. Mimosa pudica: Lajjalu. Phytopharm 2007;8:3-8.

22. Chatterjee A, Pakrashi SC. The Treatise on Indian Medicinal Plants. New Delhi: National Institute of Science Commission and Information Resources; 2006. p. 65-6.

23. Yuan K, Lü JL, Yin MW. Chemical constituents of C-glycosylflavones from mimosa pudica. Yao Xue Xue Bao 2006;41:435-8.

24. Choudhary MD, Chakrabarti P. Cellular and chloroplast lipid composition of the leaves of Mimosa pudica. Phytochemistry 1980;19:19-23.

25. Milne A, Beamish T. Inhalational and local anesthetics reduce tactile and thermal responses in Mimosa pudica. Can J Anaesth 1999;46:287-9.

26. Sridharan S, Vaidyanathan M, Venkatesh K, Nayagam AA. GC-MS study and phytochemical profiling of Mimosa pudica Linn. J Pharm Res 2011;4:741-2.

27. Saraswat R, Pokharkar R. GC-MS studies of Mimosa pudica. Int J Pharm Tech Res 2012;4:93-8.

28. Rajaram S. Health benefits of plant-derived $\alpha$-linolenic acid. Am J Clin Nutr 2014;100:443S-8S. 